\title{
Reconciling Indoor Air Quality and Energy Efficiency in Air-Conditioned Classrooms: Case Studies for Portugal and Macao
}

\author{
Rogério Duarte and Ingride Beltrão-Coelho
}

\begin{abstract}
Growing awareness on the subject of classroom's indoor air quality and concerns regarding the probable link between indoor air quality, student's attendance and academic performance, support recent legislation limiting classroom's indoor pollutant concentrations. A consequence of this legislation is the generalized shift towards air-conditioned classrooms and increased budgets for schools energy running costs. According to the scientific literature, demand control ventilation systems are suited for classrooms, ensuring indoor air quality and thermal comfort with significant energy savings. Based on detailed building energy simulation this paper compares a demand control ventilation system and a (traditional) constant air volume system considering a typical classroom located in two distinct climatic regions: Portugal and Macao. Based on hourly results of classroom's indoor $\mathrm{CO}_{2}$ concentrations and indoor air temperatures, and on annual air-conditioning energy consumptions, advantages of the demand control ventilation system are discussed.
\end{abstract}

Index Terms-Classroom indoor air quality, demand control ventilation, energy efficiency, thermal comfort.

\section{INTRODUCTION}

Several European governments have decided to invest in rebuilding and refurbishing their stock of existing public schools. According to Mumovic [1], UK's government is commited to a $£ 45$ billion program dedicated to the rebuilding of secondary schools in England and Wales. Gertis [2] states that during the current decade, Germany will invest $€ 73$ billion in the rebuilding and refurbishing of public school buildings. The Portuguese government has also invested in the rebuilding of over 100 existing secondary schools [3] and a trend that favors cyclic rebuilding instead of new construction is foreseeable in Europe, in the future.

These large scale public investments take place at a time of growing awareness on the subject of classroom's indoor air quality (IAQ) [4], [5] and of concern regarding the probable link between IAQ and student attendance and academic performance [6]-[10].

International standards [11], [12] state limits to the maximum concentrations of indoor air pollutants, and European Member States legislate on the subject [13]. Southwest Asian countries share similar concerns on IAQ,

Manuscript received December 4, 2012; revised February 5, 2013.

R. Duarte is with the Setubal Polytechnic Institute, IPS Campus, Estefanilha, 2910-761 Setúbal, Portugal (e-mail: rogerio.duarte@estsetubal.ips.pt).

I. Beltrão-Coelho is with the Independent Architect and Consultant in Sustainability and Energy Efficiency, Rua do Campo, n. 206, Edif. Fu Luen 29 D, Macau. having different indoor air quality and green building labeling methods available.

Traditionally, European classrooms were naturally ventilated; in warmer Mediterranean countries classrooms were often neither heated nor cooled. However, the need to ensure indoor pollutant concentrations below specific maxima imposes the use mechanical ventilation; therefore all rebuilt and refurbished schools now include heating and cooling systems, used to remove the fresh air thermal loads and remove the classroom thermal loads.

These "new" retrofitted schools, with air-conditioned classrooms, represent a "paradigm shift" in Europe, especially for Mediterranean countries. An important consequence of this "shift" is being felt at school administration boards, which are now facing a significant increase in schools energy running costs. The use of energy efficient air-conditioned systems is essential to minimize the problems associated with excessive increase in energy running costs.

Macao and southwest Asian conditions are very different from those in Europe; nevertheless, European design guidelines are a strong influence in Macao's and Hong-Kong's building construction ${ }^{1}$. Due to the hot and humid climate, classrooms of southwest Asia are typically air-conditioned, and the associated energy running costs are accepted as the price to pay for indoor thermal comfort. According to [14], a significant amount of Hong Kong's building sector electricity costs is related to air-conditioning. To reduce the air-conditioning payload there is the need to study the use of energy efficient air-conditioned systems: systems that ensure indoor air quality, thermal comfort, and, simultaneously, reduce energy consumption.

This paper first defines a typical classroom that meets contemporary international standards. The use of a Demand Control Ventilation (DCV) system that modulates the fresh airflow rate into the classroom based on indoor $\mathrm{CO}_{2}$ concentration measurements is then introduced. The modeling of the classroom and HVAC system is described for two distinct locations: Portugal, representing the Mediterranean mild climate, and Macao, representing the hot and humid climate of southwest Asia. Finally, results are presented and the advantages of the DCV system are discussed.

\section{TyPICAL ClassRoOM}

The classroom that will be used in this study has the

1. For Macao, especially after the nineteen-eighties. 
geometry presented in Fig. 1 and represents a typical 25-30 students classroom. With approximately $50 \mathrm{~m}^{2}$ floor surface, has comfortable headroom, generous window area facing south $^{2}$ and a depth $(6 \mathrm{~m})$ that does not exceed three times the height of the windows. Access to the classroom is made through a door to a north facing daylighted corridor that is also used to access contiguous classrooms (to the east and west). The typical classroom is located in an intermediate floor.

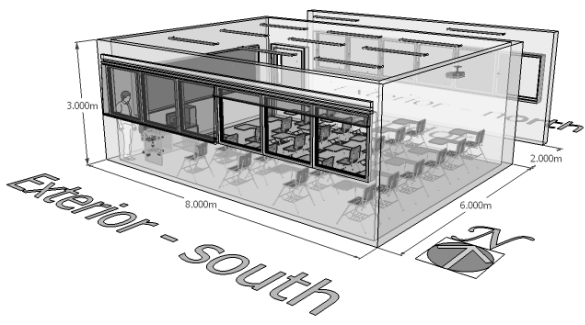

Fig. 1. Typical classroom.

Table I presents further classroom characteristics. When justified, distinctions are made between Macao (MAC) and Portugal (PT). It is important to emphasize that some of the characteristics may not represent the most common ones at each location; the objective is to study a retrofitted classroom with updated equipments and building materials.

TABLE I: RETROFITTED CLASSROOM'S CHARACTERISTICS

\begin{tabular}{cc}
\hline \hline Characteristic & Description \\
\hline Window glazing & Double 3mm-13mm-3mm; clear (PT) \\
Window frame & Single 6mm; tinted (MAC) \\
Solar control & Metal framing \\
Lighting & Exterior light colored shades (PT) \\
Equipments & Interior light colored shades (MAC) \\
\hline \hline
\end{tabular}

\section{Demand Control Ventilation}

Whenever a room has a high occupancy density - such as classrooms - typical design fresh airflow rates are usually enough to remove the room thermal loads. For mild climates, such as that of Mediterranean countries, removing the outdoor air thermal loads ${ }^{3}$ can be enough to provide thermal comfort. For the hot and humid climate of Macao removing the outdoor air thermal loads is not enough and the supply air is typically $8-15 \mathrm{~K}$ below the indoor temperature set point.

But actual classrooms occupancy patterns can be quite different from the ones typically used when designing Heating, Ventilating and Air-Conditioning (HVAC) systems. Classrooms occupancy may change due to absenteeism, breaks between classes, field trips, etc. The opening of doors (or windows) also has a significant influence on the classroom ventilation and, IAQ. A traditional Constant Air Volume (CAV) system will continue to supply a fixed amount of fresh air to the classrooms, regardless of how they are being used. A DCV system has the advantage of varying

\footnotetext{
${ }^{2}$ For Macao's hot climate, instead of reducing the winter heating loads, the south facing windows increase the classroom's cooling loads. This orientation is justified only if adequate solar and daylighting control devices are used.

${ }^{3}$ Cooling or heating the outdoor air to a supply temperature similar to the indoor setpoint temperature, between $20^{\circ} \mathrm{C}$ and $26^{\circ} \mathrm{C}$.
}

the airflow rate to every classroom (or group of classrooms) depending on the indoor $\mathrm{CO}_{2}$ concentration in the classrooms. If a classroom is at its maximum occupancy, $\mathrm{CO}_{2}$ will rise rapidly and the DCV system will modulate the fresh airflow rate to a maximum. However, if the occupancy decreases, the $\mathrm{CO}_{2}$ concentration will also decrease, and the DCV system will reduce the fresh airflow rate so that IAQ is ensured and the indoor air temperature set point is kept.

Scientific and technical literature discusses the benefits of DCV systems [15] - [18]. According to [17] implementing DCV systems in schools can save from $20 \%$ to $40 \%$ of the air-conditioning energy consumption. This argument has certainly contributed to the frequent use of DCV systems in USA school buildings.

Fig. 2 presents a schematic diagram of a DCV system. Variable Air Volume (VAV) boxes can be modulated to control the airflow rate supplied to each classroom. $\mathrm{CO}_{2}$ concentration inside the classroom is measured and a control system commands actuators that open or close the VAV box dampers. An Air Handling Unit (AHU) is used to filter, heat or cool (and dehumidify) the outdoor air. The AHU also includes an exhaust air heat recovery module.

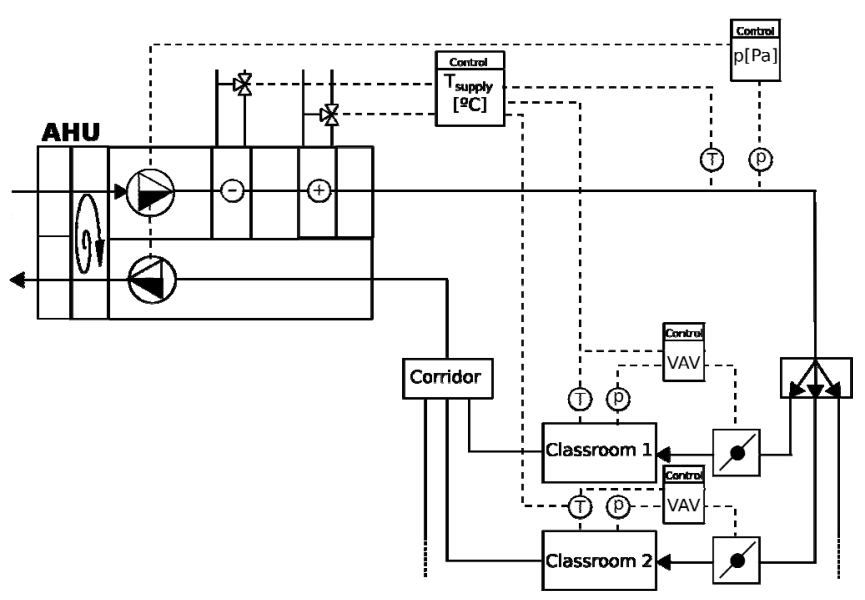

Fig. 2. Schematic diagram of a DCV airflow network, representing VAV boxes, $\mathrm{AHU}$, sensors (pressure, temperature, $\mathrm{CO}_{2}$ ), and actuators.

\section{MODELING}

EnergyPlus version 6-0-0 [19] was used to model the classroom geometry and the characteristics presented in section II. Hourly results describing the classroom IAQ and thermal behavior were obtained considering DCV and CAV systems, luminance and solar control systems.

The TRY weather files for Lisbon (Portugal) and Macao [20] were used to represent hourly averaged outdoor conditions.

\section{A. Internal Gains and Schedules}

Table II presents specific power released in the classroom due to occupancy, artificial lighting and equipments.

Classroom was assumed occupied in working days from 15 September to 15 June, from 8 AM to 12 PM and 13 PM to $18 \mathrm{PM}$, with two fifteen days holiday periods during Christmas and Easter. Classes last for 90 minutes with 15 minutes breaks. This same schedule was used for equipment. Regarding artificial lighting, for cleaning purposes lights were turned on one hour earlier, at 7 AM. 
TABLE II: CLASSROOM’S INTERNAL GAINS

\begin{tabular}{cc}
\hline \hline Classroom & Internal gain \\
\hline Occupancy & 0.45 person $/ \mathrm{m}^{2}(\mathrm{PT}) ; 0.50$ person $/ \mathrm{m}^{2}$ (MAC); \\
(total gains) & $86.25 \mathrm{~W} /$ person \\
Artificial lighting & $8.3 \mathrm{~W} / \mathrm{m}^{2}$ \\
Equipment & $12.5 \mathrm{~W} / \mathrm{m}^{2}$ \\
(sensible gains only) & \\
\hline \hline
\end{tabular}

\section{B. Systems' Setpoints}

Category II of standard EN15251:2007 [11] was used in defining the setpoints for luminance and solar control systems and for the HVAC systems - see Table III.

TABLE III: SYSTEMS’ SETPOINTS (BASED ON CATEGORY II OF EN15251:2007)

\begin{tabular}{ccc}
\hline \hline System & Control variable & Setpoint \\
\hline Daylighting control & $\begin{array}{c}\text { Luminance [lux] } \\
\text { (at the working plane) }\end{array}$ & 300 \\
$\begin{array}{c}\text { Solar control } \\
\text { HVAC }\end{array}$ & $\mathrm{CO}_{2}$ concentration $[\mathrm{ppm}]$ & 19 \\
(DCV) & $\begin{array}{c}\text { above outdoor air concentration } \\
\text { HVAC }\end{array}$ & $500^{\text {(a) }}$ \\
$\begin{array}{c}\text { Min. operative temperature }\left[{ }^{\circ} \mathrm{C}\right] \\
\text { Winter season }(1 \text { clo) }\end{array}$ & 20 \\
HVAC & $\begin{array}{c}\text { Max. operative temperature }\left[{ }^{\circ} \mathrm{C}\right] \\
\text { (DCV \& CAV) }\end{array}$ & 26 \\
\hline \hline
\end{tabular}

a) Assuming an outdoor $\mathrm{CO}_{2}$ concentration of $400 \mathrm{ppm}$, the maximum classroom $\mathrm{CO}_{2}$ concentration becomes $900 \mathrm{ppm}$.

Luminance setpoint was defined at desk surface. Two stage (150 lux each) artificial lighting was considered. When daylighting alone produces luminance levels higher than 300 lux, artificial lighting is switched off. When daylighting is not enough to obtain 150 lux at desk surface, both stages of artificial lighting are switched on.

Solar control is made possible by modulating the position of the shading devices. The control variable used is the UGR glare index [11] measured at the blackboard plane. Solar control system authority is higher than that of the daylighting control system.

The $\mathrm{CO}_{2}$ concentration setpoint is available only for the DCV system and the IAQ control is ensured by the VAV boxes in Fig. 2. Both the DCV and the CAV systems control the indoor air temperature ${ }^{4}$. The CAV system varies the supply air temperature with a constant fresh airflow rate (8 1/s/occupant). The DCV system also varies the supply air temperature, and, if necessary, increases the fresh airflow rate (above what is necessary to ensure IAQ) until a maximum equal to the CAV system constant airflow rate.

When modeling the Portuguese climate, supply air temperatures varied between $20^{\circ} \mathrm{C}$ and $23^{\circ} \mathrm{C}$ (implementing a system that is limited to removing the outdoor air thermal loads). For the hot and humid climate of Macao, lower supply air temperatures were allowed (minimum of $\left.14^{\circ} \mathrm{C}\right)^{5}$. that:

The HVAC's system modeling was validated by checking

1) Supply airflows to classroom were the ones set for the CAV system; and did not exceed the maximum or minimum set for the DCV system;

\footnotetext{
${ }^{4}$ For the DCV system, IAQ control authority is higher than that of indoor air temperature control.

${ }^{5}$ For Macao, thermal comfort requires the removal of classroom thermal loads. Since these loads vary among classrooms (because of differences in orientation, for example), classrooms with similar loads are grouped and connected to specific AHU.
}

2) Heat recovery of exhausted air was correctly computed, given the outdoor and exhaust air conditions;

3) The behavior of the DCV system correctly took into account the indoor $\mathrm{CO}_{2}$ concentration setpoint;

4) The indoor air temperatures were consistent with the implemented control laws.

Fig. 3 presents a detail of the output of EnergyPlus for a hot summer day, when the typical classroom is modeled with the DCV system. Lines for hourly supply airflow rate $\left(\mathrm{m}^{3} / \mathrm{s}\right)$ and $\mathrm{CO}_{2}$ concentration levels (ppm) in the classroom are shown.

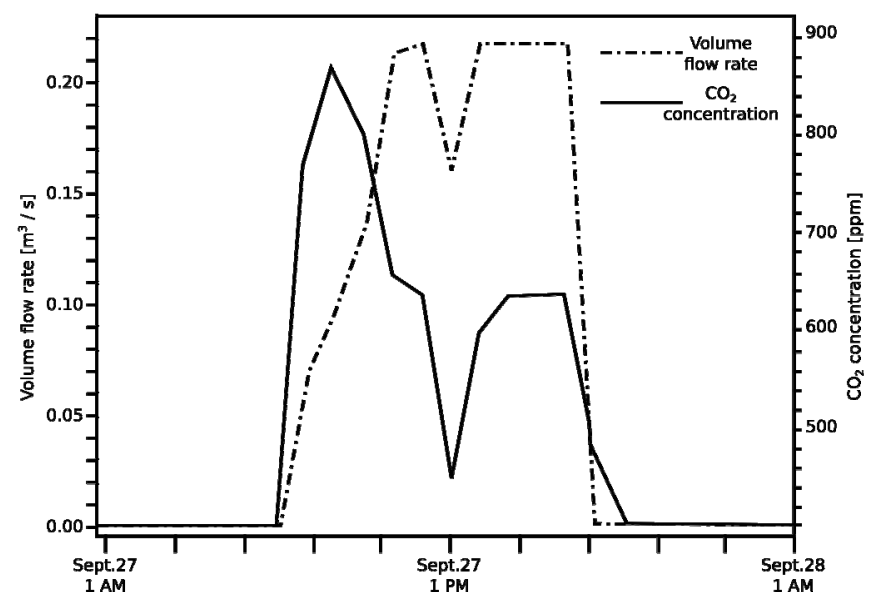

Fig. 3. Hourly airflow rate and $\mathrm{CO}_{2}$ concentration in a hot summer day: Example of DCV system control.

Fig. 3 shows a significant increase in the classroom's $\mathrm{CO}_{2}$ concentration at the beginning of the occupancy period, with a resulting increase in the airflow rate supplied to the classroom, necessary to prevent indoor $\mathrm{CO}_{2}$ concentrations in excess of $900 \mathrm{ppm}$. Because of the increasing outdoor air temperature (which exceeds $30^{\circ} \mathrm{C}$ by the end of the morning), airflow rate continues to increase, not because of IAQ, but to maintain indoor air temperatures lower than the maximum setpoint $\left(26^{\circ} \mathrm{C}\right)$. This justifies the low $640 \mathrm{ppm} \mathrm{CO}_{2}$ concentration, below the $900 \mathrm{ppm}$ setpoint. As expected, during the lunch break the DCV system reduces the fresh airflow rate.

Regarding infiltration / natural-ventilation into the classroom, the "DOE2 model" described at Energy Plus manual [19] was considered. Whenever mechanical ventilation is switched on infiltration flow rates were reduced by $75 \%$.

\section{RESUlts}

EnergyPlus results were used to compare the performance of DCV and CAV systems. For Portugal both systems removed only the outdoor air thermal loads and the range of supply air temperatures $\left(20-23^{\circ} \mathrm{C}\right)$ supports freecooling. For Macau, supply air temperatures range from the $20^{\circ} \mathrm{C}$ required to remove outdoor air thermal loads in colder mornings, to the $14^{\circ} \mathrm{C}$ necessary to ensure comfort indoor air temperatures during the rest of the day.

For the occupancy schedule presented in section IV.A, a total of 1740 hours were modeled per academic year. The hourly results were combined and presented as:

1) Means, standard deviations, maxima and minima; 
2) Percentage of hours with indoor temperature $\left(T_{\text {in }}\right)$ below a minimum $\left(T_{\min }=19.5^{\circ} \mathrm{C}\right)$ and average deviation from this limiting value - see (1) and (2);

3) Percentage of hours with indoor temperature above a maximum $\left(T_{\max }=26.5^{\circ} \mathrm{C}\right)$ and average deviation from this limiting value;

4) Percentage of hours with indoor $\mathrm{CO}_{2}$ concentration above a maximum $\left(c_{\max }=950 \mathrm{ppm}\right)$ and average deviation from this limiting value.

Equations (1) and (2) ${ }^{6}$ are presented for item (ii) above; equivalent expressions were used for items (iii) and (iv).

Hours with $T_{i n}<T_{\min }[\%]=\frac{\sum_{i=1}^{n} H\left(T_{\min }-T_{i n, i}\right)}{n}$

Mean deviation

from $T_{i n}=T_{\min }$

when $T_{\text {in }}<T_{\min }\left[{ }^{\circ} \mathrm{C}\right]=$

$$
\frac{\sum_{i=1}^{n}\left(T_{i n, i}-T_{\min }\right) H\left(T_{\min }-T_{i n, i}\right)}{\sum_{i=1}^{n} H\left(T_{\min }-T_{i n, i}\right)}
$$

\begin{tabular}{|c|c|c|c|c|}
\hline & & Outdoor & & \\
\hline & & Environment & $\begin{array}{l}\text { DCV } \\
\text { system }\end{array}$ & $\begin{array}{l}\text { CAV } \\
\text { system }\end{array}$ \\
\hline Infiltration & Average & - & 0.4 & 0.4 \\
\hline [a.c.h.] & Standard deviation & - & 0.1 & 0.1 \\
\hline & Maximum & - & 0.8 & 0.8 \\
\hline & Minimum & - & 0.0 & 0.0 \\
\hline Mechanical & Mean & - & 4.0 & 5.6 \\
\hline ventilation & Standard deviation & - & 1.4 & 0.1 \\
\hline [a.c.h.] & Maximum & - & 5.8 & 5.8 \\
\hline & Minimum & - & 1.6 & 5.4 \\
\hline Temperature & Mean $\left[{ }^{\circ} \mathrm{C}\right]$ & 16 & 25 & 25 \\
\hline & Standard deviation $\left[{ }^{\circ} \mathrm{C}\right]$ & 5 & 2 & 2 \\
\hline & Maximum $\left[{ }^{\circ} \mathrm{C}\right]$ & 32 & 31 & 31 \\
\hline & Minimum $\left[{ }^{\circ} \mathrm{C}\right]$ & 4 & 18 & 18 \\
\hline & Hours with $T_{\text {in }}<T_{\min }[\%]$ & 80 & 0 & 0 \\
\hline & Hours with $T_{\mathrm{in}}>T_{\max }[\%]$ & 5 & 16 & 15 \\
\hline & $\begin{array}{l}\text { Mean deviation when } \\
T_{\text {in }}<T_{\min }\left[{ }^{\circ} \mathrm{C}\right]\end{array}$ & -6 & - & - \\
\hline & $\begin{array}{l}\text { Mean deviation when } \\
T_{\text {in }}>T_{\max }\left[{ }^{\circ} \mathrm{C}\right]\end{array}$ & 2 & 1 & 1 \\
\hline $\mathrm{CO}_{2}$ & Mean [ppm] & 400 & 770 & 647 \\
\hline concentration & Standard deviation [ppm] & 0 & 115 & 18 \\
\hline & Maximum [ppm] & - & 975 & 677 \\
\hline & Minimum $[\mathrm{ppm}]$ & - & 604 & 603 \\
\hline & Hours with $c_{\mathrm{CO} 2}>c_{\max }[\%]$ & 0 & 1 & 0 \\
\hline & $\begin{array}{l}\text { Mean deviation when } \\
c_{\mathrm{CO} 2}>c_{\max }[\mathrm{ppm}]\end{array}$ & - & 17 & - \\
\hline Specific & Heating $\left[\mathrm{W}_{\text {thermal }} / \mathrm{m}^{2}\right]$ & - & 1.3 & 6.6 \\
\hline energy & Cooling $\left[\mathrm{W}_{\text {thermal }} / \mathrm{m}^{2}\right]$ & - & 1.9 & 1.9 \\
\hline consumption & Ventilation $\left[\mathrm{W}_{\text {electricity }} / \mathrm{m}^{2}\right]$ & - & 1.9 & 2.7 \\
\hline & Total $\left[\mathrm{W}_{\text {electricity }} / \mathrm{m}^{2}\right]$ (a) & - & 2.8 & 5.0 \\
\hline
\end{tabular}

(b) Considering EER $=3$ and $\mathrm{COP}=4$ for the production of cold and hot water.

Tables IV and V present classroom's $\mathrm{CO}_{2}$ concentrations, indoor air temperatures, and air-conditioning systems energy consumptions, for Portugal and Macao, respectively.

The results show that:

1) Regarding IAQ, DCV and CAV systems perform equally well.

2) For Portugal, with the DCV system, $\mathrm{CO}_{2}$ concentrations exceed the $950 \mathrm{ppm}$ limit during 1\% (17 hours) of the annual occupancy period. However, the average

\footnotetext{
${ }^{6} \mathrm{H}$ represents the left-continuous Heaviside function.
}

deviation from the $950 \mathrm{ppm}$ limit is $17 \mathrm{ppm}$.

3) Due to the higher occupancy (see Table II), for Macao, and with the DCV system, $\mathrm{CO}_{2}$ concentrations exceed the 950 ppm limit during 16\% (278 hours) of the annual occupancy period. However, the average deviation from the $950 \mathrm{ppm}$ limit is just $33 \mathrm{ppm}$ and the maximum $\mathrm{CO}_{2}$ concentration hardly exceeds $1000 \mathrm{ppm}$.

4) Regarding indoor air temperatures, DCV and CAV systems perform equally well.

5) Regarding energy consumption, the DCV enables significant energy savings.

6) For Portugal, the DCV system allows (total) electricity savings of approximately $40 \%$; with $80 \%$ less electricity spent for heating $(\mathrm{COP}=4)$ and $30 \%$ less electricity spent for ventilating.

7) For Macao, the DCV system (total) electricity saving amounts to just $10 \%$. This is related to the uniform load/occupancy patterns imposed on the DCV system, which runs for longer time periods closer to nominal conditions.

TABLE V: RESULTS USING DCV AND CAV SYSTEMS IN MACAO.

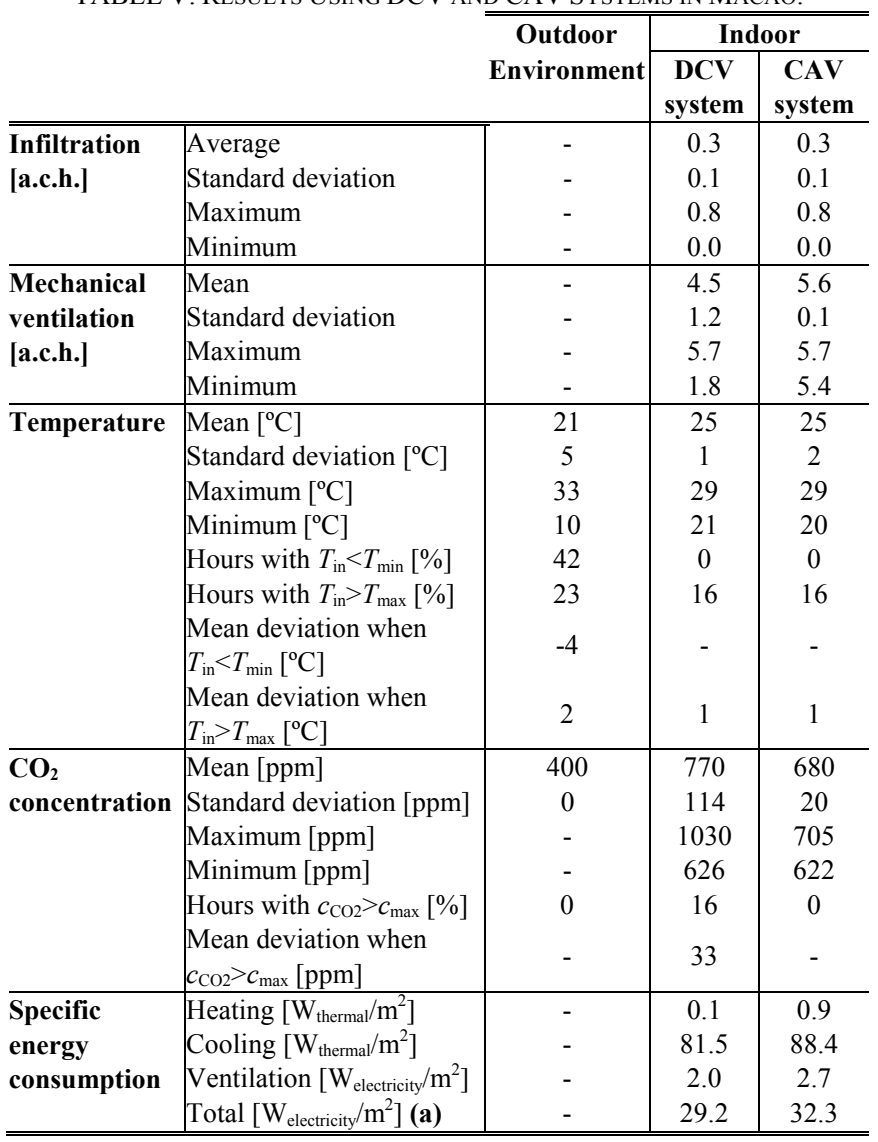

(c) Considering EER $=3$ and $\mathrm{COP}=4$ for the production of cold and hot water.

\section{CONCLUSION}

The results show that the DCV system ensures IAQ and comfort indoor air temperatures with fresh airflow rates lower than typical design standards $(8 \mathrm{l} / \mathrm{s} /$ person $)$. The energy saving potential of the DCV system is related to the probability of partial load/occupancy. For the Portuguese mild Mediterranean climate - for which classroom thermal comfort is possible by simply removing the fresh air thermal loads -, winter conditions promote extended periods of time 
at partial load operation, with significant energy savings due to reduced ventilation rates (without compromising IAQ). During summer, solar and internal gains push air-conditioning systems to full load operating conditions, justifying Tables IV and V lower saving opportunities associated with cooling.

It should be emphasized that the results presented are for a classroom with generous window areas facing south, and with a uniform occupancy pattern. The electricity saving potential of DCV systems should increase above $10 \%$ for cooling, if the classroom orientation and occupancy pattern promote wider daily and annual thermal-load/occupancy oscillations.

\section{REFERENCES}

[1] D. Mumovic et al., "Winter indoor air quality, thermal comfort and acoustic performance of newly built secondary schools in England," Building and Environment, vol. 44, pp. 1466-1477, 2009.

[2] K. Gertis and K. Sedlbauer, "Schulsanierung," Bauphysik, vol. 32, no. 2, pp. 100-109, 2010

[3] Parque Escolar, EPE, Parque Escolar 2007-2011 - Intervenção em 106 Escolas. [Online]. Available: http://www.parque-escolar.pt/pt/ programa/livros-parque-escolar.

[4] M. Santamouris et al., "Experimental investigation of the air flow and indoor carbon dioxide concentration in classrooms with intermittent natural ventilation," Energy and Buildings, vol. 40, pp. 1833-1843, 2008.

[5] J. M. Daisey, W. J. Angell, and M. G. Apte, "Indoor air quality, ventilation and health symptoms in schools: an analysis of existing information," Indoor Air, vol. 13, pp. 53-64, 2003.

[6] U. H. Shaughnessy, D. J. Moschandreas, and R. J. Shaughnessy, "Association between substandard classroom ventilation rates and students' academic achievement," Indoor Air, vol. 21, pp. 121-131, 2011.

[7] D. J. C. Croome, H. B. Awbi, Z. B. Biro, N. Kochhar, and M. Williams, "Ventilation rates in schools," Building and Environment, vol. 43, pp. 362-367, 2008

[8] P. Wargocki and D. P. Wyon, "The Effects of Outdoor Air Supply Rate and Supply Air Filter Condition in Classrooms on the Performance of Schoolwork by Children (RP-1257)," HVAC \& R Research, vol. 13, no. 2, pp. 165-191, 2007.

[9] P. Wargocki and D. P. Wyon, "The Effects of Moderately Raised Classroom Temperatures and Classroom Ventilation Rate on the Performance of Schoolwork by Children (RP-1257)," HVAC \& $R$ Research, vol. 13, no. 2, pp. 193-220, 2007.

[10] M. J. Mendell and G. A. Heath, "Do indoor pollutants and thermal conditions in schools influence student performance? A critical review of the literature," Indoor Air, vol. 15, pp. 27-52, 2005

[11] Indoor Environmental Input Parameters for Design and Assessment of Energy Performance of Buildings Addressing Indoor Air Quality, Thermal Environment, Lighting and Acoustics, CEN Standard EN15251-2007.
[12] Ventilation for Acceptable Indoor Air Quality, ANSI/ASHRAE Standard 62.1-2007.

[13] On the Energy Efficiency of HVAC Systems, Portuguese Decree-Law $79-2006$ ( $4^{\text {th }}$ of April).

[14] Peter Gorer et al., Green' house or greehouse? Climate change and the building stock of Hon Kong and Macau, Civil Exchange. (2008). [Online]. Available: http://www.iisbeportugal.org/portugues/ documentos/downloads.html

[15] M. Apte, A review of demand control ventilation, LBNL-60170 Report, 2006.

[16] A. Persily et al., Simulations of indoor air quality and ventilation impacts of demand controlled ventilation in commercial and institutional buildings, NISTIR 7042 Report, 2003.

[17] S. Emmerich and A. Persily, State-of-the-Art review of $\mathrm{CO} 2$ demand controlled ventilation technology and application, NISTIR 6729 Report, 2001.

[18] ASHRAE Handbook - HVAC Applications (SI), American Society of Heating, Refriverating, and Air-Conditioning, Inc, 2007.

[19] EnergyPlus Engineering Reference - The Reference to EnergyPlus Calculations, The Board of Trustees of the University of Illinois and the Regents of the University of California through the Ernest Orlando Lawrence Berkeley National Laboratory, 2011.

[20] EnergyPlus Energy Simulation Software. (September 19, 2012). [Online]. Available: http://apps1.eere.energy.gov/buildings/energyplus/cfm/weather_data.c fm

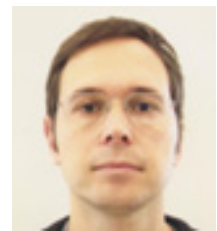

Rogério Duarte holds a $\mathrm{Ph} . \mathrm{D}$. in Mechanical Engineering from Lisbon Technical University, Portugal, and has more than 10 years of professional experience as a researcher, consultant, and teacher. $\mathrm{He}$ is a Professor at the Mechanical Engineering Department of Setúbal Politechnic Institute, Portugal, and his main research interests include energy conservation in buildings and industry. Prof. Duarte is a member of the Portuguese Engineers Society and is accredited for performing industry and building related energy audits.

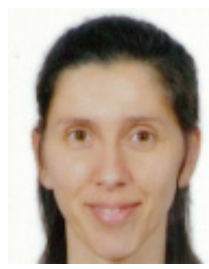

Ingride Beltrão-Coelho holds a MSc. in Bioclimatic Architecture (2008) from Lisbon Technical University - Faculty of Architecture (FAUTL) - and is interested in the fields of sustainable construction, energy efficiency and conservation, increment of renewable energies and preservation of the environment. She is a $\mathrm{PhD}$ candidate at UNESCO-TU/e Resear- ch Program "OUV, World Heritage Cities \& Sustainability" and is currently working in Macau as a freelance Architect and as a Visiting Professor at USJ. She coordinated several trainings on the subject of Residential Buildings Energy Auditing (EPDB) offered by the Portuguese Architects and Engineers Societies, and lectured for more than 6 years as Visiting Professor in MSc. and other postgraduate degrees in Portugal, including Lisbon (FAUTL), Setúbal (IPS-EST), Madeira (UMA), Azores (MIT), and SGS Portugal. Architect Beltrão-Coelho is a member of the Portuguese Architects Society and is accredited for performing building related energy audits. 